\title{
Evaluation of the Policy Implementation for Religious Education Teachers in Schools
}

\author{
Suprapto $^{1}$, Muammar Kadafi ${ }^{2}$ \\ \{supraptolitbang@gmail.com ${ }^{1}, \underline{\text { kadafi@gmail.com }}{ }^{2}$ \} \\ Center Research for Religious Education ${ }^{1,2}$
}

\begin{abstract}
Religious education policy refers to Government Regulation (PP) No. 55 of 2007 concerning Religious Education and Religious Education. However, the fact is that religious education regulations, especially in public schools, still have to refer to the Ministry of Education regulations. This study aims to determine the implementation of religious education teacher (GPA) policies in schools related to coaching, recruitment, career development and rank, and GPA welfare. This research method uses descriptive qualitative methods, through documentation study techniques by collecting and analyzing official documents, documents whose validity is related to management regulations and the implementation of religious education in schools and in-depth interview technique. This research resulted in GPA not knowing and understanding various rules related to the Management and implementation of religious education; The Ministry of Religion experiences difficulties in developing competence and professionalism, career development, rank and in passing, the welfare of religious education teachers in schools; There is a lack of coordination between the Education Office and the Regency / City Ministry of Religion in the recruitment and placement and guidance of GPAs and inadequate budgets for GPA guidance. This study recommends the need for socialization of various regulations on the Management and implementation of religious education; There is a need for coordination between the Education Office and the Ministry of Religion at the Regional Office and District / City level in the recruitment and placement and guidance of GPAs. There is a need for an adequate budget for the direction of GPA in schools.
\end{abstract}

Keywords: Policy Evaluation, Religious, Education Teachers.

\section{INTRODUCTION}

\section{A. Background}

One of the principles of good governance is the existence of policies that help serve and facilitate the community. Some of the indicators for this policy are implementing the principles of efficiency, accountability, effectiveness, and excellent service. The community as both the recipient and the object of the policy are optimally served. Besides, the policies made by the Government aim to provide a legal umbrella for all aspects of the program being implemented. The beneficiaries and the policy objects, namely the public, also need these regulations as protection of their rights and obligations regarding the object of the regulation or policy. However, there is a hierarchy of regulations that needs attention from the highest to the lowest. Where the lowest principles must follow and or may not conflict with the regulations above. Any 
policy has references to higher regulations above it, including regulations on Islamic Religious Education.

Policies related to Religious Education refer to the 1945 Constitution, which was revealed to be Government Regulation (PP) No. 55 of 2007 concerning Religious Education and Religious Education. PP 55/2007 is the main legal umbrella for the Management of Religious Education, which is operational at the Ministry of Religion. However, the fact is that the regulations on Religious Education, especially in public schools, still refer to the Ministry of Education's relevant regulations. Research on the implementation of policies related to Religious Education will relate to 1) the policy hierarchy itself, 2) policies issued by other ministries (apart from the Ministry of Religion) but the impact or the fact that the Ministry of Religion must follow these regulations, 3) the impact on beneficiaries or target objects from the policy itself, namely the teacher of religious education as an object or issue, including the supervisor of religious education, the Ministry of Religion at the central, provincial and district/city levels as well as the object and implementer of the policy. This impact can be in the form of a derivative structure or policy or translation that must be done so that the main policy can be implemented 4) and implementation in the field. So that the sequence of these regulations can be mapped and the impact that occurs on regulations on recipients or objects of regulation and implementation.

In general, the policy will be seen from 1) the substance of the policy, 2) the objectives of the regulation, 3) the expected impact, 4) the impact that occurs or the reality of the policy, and 5 ) the implementation of policy implementation at the lower level and 6) interpretation of policy itself at the bottom level. At the level of reality in the field, several problems are found related to policies in the education sector with implementation in the field. For example, several policies related to the recruitment of Religious Education Teachers are under the Regional Government's authority and the Ministry of Religion. The appointment of PNS Religious Education Teachers in schools is carried out by local governments, not by the Ministry of Religion. For example, in the city of Padang, the appointment of PNS GPAI was carried out in 2014-2015, the Local Government of Padang City did not coordinate with the local Ministry of Religion. In NTB, the appointment of PNS GPAI is the authority of the Regional Government. The appointment of PNS GPAI by the Regional Government can cause problems in organizing and coaching under the Ministry of Religion's authority. This is why the Ministry of Religion wants the appointment of GPAI to be under its authority (Ma'rifataini, 2018).

Another policy that is difficult to implement is the coaching and career development of CL Teachers and PA Supervisors. PA teachers who are appointed by the Ministry of Religion find it difficult to develop a career in public schools even though there is a legal umbrella that allows PA teachers who are appointed by the Ministry of Religion to develop careers as school principals. Regarding the development of Religious Education Teachers, it is the same; the lack of budget for the Ministry of Religion has hampered access to PA Teachers in the form of teacher professional development. Meanwhile, the Education Office, which also has the same duty to foster PA teachers, argues that their PA teachers are under the Ministry of Religion's authority. According to I Gede Jaman, a solution to reducing the problem of training for Hindu religious teachers was the formation of the KKG Organization for the Guidance Teachers of Religion Hindu at the basic level, and the MGMP Organization for the coach of intermediate level religious teachers. For direct guidance through the regional office (provincial supervisors), the frequency is still very small. 
This includes the welfare of Religious Education Teachers and Religious Education Supervisors who are constrained by regulations. An example is the access of PA teachers to get the opportunity to be certified or to take part in passing. Existing policies cannot accommodate the ease of access for GPA, access to take the certification, or in passing. This is what makes the research "Implementation of Religious Education Teacher Policies in Schools" important. This research will look at "suspected" policies to be problematic or cause problems at the field's implementation level.

\section{B. Research Objectives}

The purpose of this study was to determine:

1. The level of understanding of policymakers and implementers (Head of Provincial Ministry of Religion, Kasi PA at District / City level, PA Teachers, PA Supervisors, and Head of Education Office) regarding recruitment policies, coaching, career development, and Welfare of Religious Education Teachers.

2. Implementing CL teacher policies related to coaching, recruitment, career development, and rankings of CL teachers and PA teachers' welfare.

3. Constraints faced in implementing policies for Religious Education Teachers.

\section{Benefits}

The results of this study are expected to be useful as input for the Directorate General of Islamic Education of the Ministry of Religion, especially the Directorate of Islamic Religious Education in Schools, the Directorate General of Christian, Catholic, Hindu, and Buddhist and Confucian Community Guidance in making policies related to Regulation of Religious Education Teacher Policy in schools.

\section{Research Methodology}

Types and Research Approaches

To obtain the required data and information and to answer the formulation of the study's problems, the type of research used is descriptive research with a qualitative approach. Research with descriptive type solves problems by describing the subject/research object's current state/research object based on visible facts. In short, it can be said that descriptive research is the steps to represent the research object about the symptoms found in the research problem (Nawawi, 2005).

This type of descriptive research is based on research objectives that want to know the problems faced in implementing CL teacher policies, the level of understanding of the implementers and policymakers of CL teacher policies, and the problems faced in implementing these PA teacher policies. This is based on a very broad scope of regulations, so that the selection of this method can explain in detail and clearly describe the problems that arise in implementing CL policies, which are limited to issues of recruitment, coaching, career and rank development, and welfare.

\section{Data Collection Techniques}


Data collection The research was conducted through in-depth interviews, filling out questionnaires (list of contents) to implementers and policymakers to find solutions to existing religious education teacher policy problems.

\section{Data Analysis Techniques}

To obtain maximum results, the authors use discrepancy analysis. With this technique, the design (ideal formulation) according to the policy regulations' sound will be compared with the das sollen (reality on the ground) experienced/practiced by the implementer.

\section{Research Location}

This research was conducted in Bandung City, West Java. The reasons for choosing the location were: based on the administrative area and geographic location by taking into account areas that have variants of the diversity of minorities and the majority of adherents of their Religion. They have religious teachers who are the majority of the population.

\section{THEORETICAL STUDY}

\section{A. Policy on Management of Religious Education Teachers The}

Management of religious education teachers consists of two words, namely Management and religious education teachers. Management comes from the word "manage," which is added with the prefix "pe" and the suffix "an" so that it means the process of carrying out certain activities by mobilizing other people's power (Depdikbud, 1990). In English, Management is called "management," which comes from the word "to manage," which means organizing. So Management or Management is an arrangement carried out through a process and arranged according to the order of management functions (planning, organizing, coordinating, controlling, and evaluating) (Hasibuan, 2003). Management can also be defined as the science and art of regulating the process of utilizing human resources and other sources effectively and efficiently to achieve certain goals. According to Suharsimi Arikunto, Management is defined as organizing or managing so that something is managed to run smoothly, effectively, and efficiently (Arikunto, 1996). This opinion can be understood that the notion of Management is the same as regulating an activity. This is in line with what was conveyed by MA Amitembun, which defines Management as the same as Management, which means Management or regulation in an organization (Amitembun, 1990). According to him, good management is necessary in an organization to achieve organizational goals smoothly, effectively, and efficiently.

Meanwhile, according to GR Terry, as quoted by Malayu, Management is a typical process consisting of planning, organizing, directing, controlling actions that are carried out to determine and achieve predetermined goals through human resources and other resources (Amitembun, 1990: 3). The same thing was conveyed by Hoff, quoted by Wiyadiharja, Management, or Management is directing, or towards a business power carried out through planning, organizing, coordinating, and controlling human resources and materials aimed at achieving predetermined goals (Wiradiharja, 1987).

Furthermore, in PP 17/2010 Chapter I articles 1, 2 and 3 it is stated that: first, education management is the regulation of authority in the administration of the national education system by the Government, provincial governments, district/city governments, education providers established by the community, and education units so that the educational process can take place under the goals of national education. Second, education management is carried out by 
Government; the Provincial Government; district/city government; administrators of educational units established by the community; and educational units or programs. Third, education management aims to ensure community access to adequate, equitable, and affordable education services; quality and competitiveness of education and its relevance to society's needs and/or conditions, and effectiveness, efficiency, and accountability of education management. The policy of managing religious education cannot be separated from implementing education in general. It is under the mandate of Law Number 22 of 1999 concerning regional governance and Law Number 20 of 2003 concerning the national education system and Law Number 32 of 2004 about Regional Government. However, the implementation of religious educators in the regions still receives "discriminatory" treatment from the regional Government. This is largely due to the incomplete understanding of the regional Government regarding the terms "education" and "religion" in the two laws. There are many partial interpretations that under the authority of local governments is education under the Ministry of National Education's auspices.

Meanwhile, education under the Ministry of Religion's auspices is still under the Ministry of Religion's authority. So that there is an injustice of local government policies towards religious education teachers within the Ministry of Religion, one of which can be seen in the treatment of local governments on the welfare of religious education teachers. Husen Umar stated that to get good employees, various activities are needed, namely: planning, organizing, directing, and monitoring procurement, development, compensation, integration, maintenance, and termination of employment to achieve integrated organizational goals (Umar, 1999). Furthermore, Ari Gunawan said that to get and maintain employees properly, it is necessary to include preparation/procurement; arrangement/placement/procurement, official examinations, promotion/position, development; appraisal, and termination or employment (Gunawan, 1996).

Religious education is education that provides knowledge, skills and shapes the attitudes of students in practicing religious teachings at all paths, levels, and types of education. Religious education generally functions to form Indonesian people who believe in and fear the one and only God and have a noble character and can maintain harmonious relations between religious communities (Explanation of article 37 of Law No. 20 of 2003 on the National Education System). Also, religious education aims to foster the development of students' abilities in understanding, living, and practicing religious values that balance their mastery in science, technology, and art. Law Number 20 of 2003 in Chapter I Article 1 paragraph 1 states that teachers are professional educators with the main task of educating, teaching, guiding, directing, training, and evaluating students in early childhood education through formal education, basic education, and secondary education. Therefore, the teacher is one of the elements which must play a role and position themselves as professionals. In a special sense, it can be said that in every teacher lies the responsibility to bring his students to a certain maturity or level of maturity.

World teacher professional organizations reveal that teachers' role in schools is not only a transmitter of ideas but also as a transformer and catalyst for values and attitudes (AM, 1994). Before appearing in front of the class managing teaching and learning interactions, the teacher must first master what materials must be contacted and, at the same time, what materials can support the teaching and learning process. With the capital of mastering teaching materials, the teacher will systematically and dynamically deliver subject matter. For this reason, a teacher is obliged to meet the requirements not only as a smart person but also as a virtuous person, a 
believer whose own actions can have an impact on the souls of his students. It's not only what he teaches that matters; but what he does, the way he carries himself, his attitude inside and outside the classroom, all are expected to be under the ideals that are, without the doubt, slightest accepted by his students (Husen, Syed Sajjad, 1994).

Based on the reference above, what is meant by the policy of managing religious education teachers is the authority of the Local Government in the procurement and guidance of GPAI in schools. Procurement indicators include the person in charge of the procurement of GPAI, the number of GPAI appointed by the Ministry of Religion and the Regional Government, the number of GPAI NIP 15, and NIP 13. While the guidance indicators include the person in charge of coaching, increasing professionalism, career development, welfare, and evaluating religious education teachers.

\section{B. Religious Education Teachers}

In-Law Number 14 of 2005 concerning teachers and lecturers in Chapter I Article 1 paragraph 1 , it is stated that teachers are professional educators with the main task of educating, teaching, guiding, directing, training, and evaluating students in early childhood education pathways. Formal education, basic education, and secondary education. Therefore, the teacher is one of the elements which must play a role and position themselves as professionals. In a special sense, it can be said that in every teacher lies the responsibility to bring his students to a certain maturity or level of maturity.

World teacher professional organizations reveal that teachers' role in schools is not only a transmitter of ideas but also as a transformer and catalyst for values and attitudes (AM, 1994). Before appearing in front of the class managing teaching and learning interactions, the teacher must first master what materials must be contacted and, at the same time, what materials can support the teaching and learning process. With the capital of mastering teaching materials, the teacher will systematically and dynamically deliver subject matter. For this reason, a teacher is obliged to meet the requirements not only as a smart person but also as a virtuous person, a believer whose own actions can have an impact on the souls of his students. It's not only what he teaches that matters; but what he does, the way he carries himself, his attitude inside and outside the classroom, all are expected to be under the ideals that are, without the doubt, slightest accepted by his students (Husen, Syed Sajjad, 1994).

In-Law No. 14 of 2005 on teachers and lecturers in Chapter IV Articles 8, 9, and 10, several teachers' aspects are emphasized. Among them are that teachers must have academic qualifications, competencies, teacher certificates, be physically and mentally healthy, and realize the goals of national education. Competence referred to in this case, includes pedagogic competence, personality competence, social competence, and professional competence obtained through professional education. This is in line with the Law. No. 20 of 2003 concerning the National Education System in Article 12 paragraph 1.a mandates that every student in each education unit has the right to receive religious education under his / her Religion and is taught by religious education. Every educational staff, including religious teachers, is obliged to carry out their duties with full responsibility and dedication to improve their professional abilities under the demands of science and technology and national development. 


\section{GENERAL DESCRIPTION OF THE RESEARCH LOCATION}

\section{A. Community Overview}

Bandung is located in West Java and is the capital of West Java Province, located between $107^{\circ}$ East Longitude and $6.55^{\circ}$ South Latitude. Based on this position, Bandung's city is in a strategic location in terms of communication and economic potential. This is because the city of Bandung is located at the intersection of the main road axis on Java, namely: 1. EastWest, in this position, Bandung's city becomes the central axis that connects Banten and Central Java's capital city. 2. Apart from being the main link between the State Capital and the South, North and South also serves as a meeting point between plantation-producing areas with livestock and fisheries.

Bandung City consists of 30 Districts, 151 Sub-Districts, and has an area of $65 \mathrm{Ha}$. The area is based on the Bandung City Level II Regional Municipal Regulation Number 10 of 1989 concerning Changes in the Regional Boundary of the Bandung Level II Regional Municipality, which is a follow-up to the issuance of Government Regulation Number 16 of 1987 concerning Changes in the Regional Boundary of the Bandung Level II Regional Municipality with the Bandung District Level II.

Labor Out of the total population of people, the total workforce of Bandung City in 2017 is as many as people, and the labor force participation rate is $90.83 \%$. The number of this workforce increased $3.70 \%$ from the previous year, which was only people. The increase in job absorption, which continues to increase in line with the increase in investment and economic growth in Bandung, causes a decrease in the unemployment rate in 2012 to be $9.17 \%$ from last year's 10.34. (BPS Java Province, 2017).

\section{B. The State of Schools and Teachers of Religious Education}

As the capital of West Java Province, Bandung is the city with the highest human development index (HDI). In 2017, the HDI for Bandung City reached 80.31. The average length of schooling for Bandung City residents in 2017 is 10.59 years or class 10 SMA. The average length of schooling for Bandung City residents is higher than the average length of schooling for West Java residents, which is 8.14 years. This condition shows that the entire population in Bandung City has undergone primary and secondary education as mandated in Law No. 20 of 2003 concerning the National Education System states that every citizen aged seven to fifteen is obliged to attend basic education. Basic education referred to here is in the form of Elementary School (SD), Madrasah Ibtidaiyah (MI), or other equivalent forms, as well as Junior High School (SMP) or Madrasah Tsanawiyah (Mts) or other equivalent forms. One of the indicators used to see education development is the school enrollment rate (APS).

From the National Socio-Economic Survey (Susenas) data held by the Central Statistics Agency (BPS), in 2017, the Bandung City School Participation Rate (APS) for children aged 5-6 years was 15.27 percent. This means that 15.27 percent of the population aged 5-6 years have taken formal and non-formal education. The APS for Bandung City has 7-12 years old and a population of 13-15 years, respectively 99.82 years and 95.55 percent. In other words, there are 0.18 percent of the population aged 7-12 years and 4.45 percent of the population aged 13-15 who are not currently studying, both formal and non-formal in Bandung City. The APS for the population aged 16-18 years is even lower, at 75.42 percent. This is quite surprising because it 
turns out that there are still children in Bandung who are so advanced that they have not undergone education as mandated by Law.

The number of schools or educational institutions in the city of Bandung is sufficient to accommodate children studying. From data from the Ministry of Education and Culture in 2017, which are spread across 30 districts, there is 472 SD (10,319 teachers and 229,718 students), 246 junior high schools (5,286 teachers and 107,890 students), 139 high schools $(3,845$ teachers and 62,132 students, 128 vocational schools (3,570 teachers and 62,520 students) and 45 special schools in Bandung City.

The Government has also implemented various policies to simplify the community's education process, such as School Operational Assistance and Smart Indonesia Cards. However, this is not enough to get all children in Bandung to go to school. Results in a child not going to school Several studies have shown that the cause of a child not attending school may come from the family, school, environment, or even the child himself. There needs to be a role from various parties to help increase children's school participation. As mandated in the Law that every citizen of the state is responsible for the sustainability of education, the compulsory education age population's parents must provide basic education to their children. Parents need to understand that education is important for their children's future. Likewise children, where every child needs to be given an understanding of why education, in this case, school, is important for him. A child needs to be given the understanding that a school is a place for him to develop his abilities to have a quality future in his adult life. A child needs to be guided to find the motivation to study for himself. Schools, as one of the places where children undergo the educational process, need to provide understanding to their students, parents, and the community that education is indispensable for every child. Schools need to make every educational process at every level a fun process to attract children's interest in learning. The Government is obliged to provide a quality education that can be accessed easily by all society levels. Children need education. It is undeniable that the era of globalization has made the individual competition even tighter. If children are not equipped with good knowledge, understanding, skills, and character, it will be difficult for them to compete.

\section{UNDERSTANDING OF THE POLICIES OF DEVELOPMENT, RECRUITMENT, CAREER DEVELOPMENT \& DEVELOPMENT AND WELFARE BY POLICY STAKERS AND IMPLEMENTERS}

\section{A. Head of Bandung City Education Office}

The procurement of education teachers at schools can be done through two channels. Namely, the Ministry of Religion and Local Government is not the most important problem in this matter. Each school can meet the needs of religious education teachers without questioning whether religious education teachers are appointed by the Ministry of Religion or the Regional Government. It is also under the existing legal umbrella, such as Law No. 20 of 2003 on the National Education System, Law No. 22 of 1999 concerning Regional Government, Law No.32 of 2004 concerning Regional Autonomy, PP. 55 of 2007, concerning religious education and 
religious education, PP. 74 of 2008 concerning teachers and PP No. 17 of 2010 concerning the Management and implementation of education.

According to him, local governments' treatment towards religious education teachers appointed by the Regional Government is not differentiated from general subject teachers in various opportunities to improve their competence and professionalism, coaching, career development, and welfare benefits. Religious education teachers have received various activities in the form of seminars and workshops related to developing knowledge insights and increasing their professionalism. Besides, religious education teachers can develop careers as school principals or become structural officials within the Education Office based on achievement and performance. Religious education teachers at schools appointed by the Regional Government get a regional welfare allowance of the district/city minimum wage (UMK) of IDR 3,339,000 (three million three hundred thirty-nine thousand rupiah) as well as honorary religious education teachers at schools those who are appointed by the Regional Government also receive additional honoraria in the form of honorarium assistance to improve the quality of educators and nonteaching staff in the amount of Rp. 300,000 (three hundred thousand rupiah) per month.

The procurement of religious education teachers began with an open announcement through both print and electronic media. After the job application is accepted, it is selected administratively, followed by a written test in an Academic Potential Test and a psychological test. Then announced the exam participants who passed. ${ }^{1}$ Placements are based on the selection of prospective employees online. In this case, the Education Office does not specify.

The development of religious education teachers in schools related to competence, professionalism, career development, and welfare is also the Education Office's authority. However, it is possible to provide opportunities for religious education teachers to participate in various activities to increase the competence and professionalism of religious education teachers organized by the Ministry of Religion. According to him, the development of religious education teachers has not been maximized in terms of quantity and quality. In terms of the number of coaching in the form of seminars, workshops, orientation, and training for religious education teachers, it has not reached all religious education teachers. As for the qualitative increase in professionalism, it has not comprehensively addressed religious education teachers' duties.

B. Head of PAI, Bimas Christian, Catholic, Hindu, Buddhist, and Confucian at the Regional Office of the Ministry of Religion.

The procurement of religious education teachers at schools takes two channels. In principle, there is no problem as long as it is supported by clear regulations under PP No. 55 of 2007, concerning religious education and religious education. According to their respective authorities, article 6 paragraph (1) states that the Government or regional governments provide religious education educators in education units organized by the Government or local governments based on the provisions of the Legislation.

West Java Province, since 2006 the Ministry of Religion has no longer appointed religious education teachers to schools. The appointment is submitted to the local government

\footnotetext{
${ }^{1}$ Cucu Sampurna, Head of Guidance and Development of Education and Education Personnel (P3TK) Bandung City Education Office, Interview on 9 April 2019.
} 
through the Education Office. It was only in 2018 that the regional Government reappointed religious education teachers, both Islam (19 people), Catholic ( 2 people), Christian (12 people), and Buddhist (2 people).

The policy for procuring religious education teachers in West Java is in the hands of the Regional Government. Authority falls under the Regional Civil Service Agency (BKD). The appointment of religious education teachers is tailored to the needs; the number or formation is adjusted to the BKD or the education office's needs. The recruitment process initially proposed the procurement of religious education teachers, then the Education Office accepted the proposal and coordinated with the BKD. Then BKD proposes to BKN, which is then fulfilled by BKN according to the existing quota. In the proposal, neither the Education Office nor the BKD coordinated with the Bandung City Ministry of Religion. This reason is under the Education Office's full authority starting from the announcement, selection to placement, or there is no coordination with the Ministry of Religion at both the provincial and district/city levels. Nevertheless, the Education Office acknowledged the need for coordination with the Ministry of Religion. The BKD issues criteria or requirements for religious education teachers' appointment at schools, such as religious scholars, by looking at the transcript and diploma value.

\section{Kasi Ministry Bandung City}

The procurement of religious education teachers in Bandung schools is carried out jointly between the Ministry of Religion and the Regional Government. The procurement of these two institutions is not a problem as long as it complies with government laws or regulations, such as PP 55 of 2007 concerning Management of religious and religious education, PP 74 of 2008 Jo PP 19 of 2017 concerning Teachers and Joint Regulations of the Minister of National Education and the Head of BKN No. 01 / III / PB / 2011, Number 6 of 2011.

Administrative guidance for religious education teachers is carried out by the Education Office, while substance coaching related to the improvement and development of competence and professionalism is the Ministry's responsibility of Religion. However, in the future, the procurement of religious education teachers will be better. The authority of the Ministry of Religion is aimed at ensuring public access to adequate, equitable, and affordable education services; quality and competitiveness of education and its relevance to the needs and/or conditions of society; and effectiveness, efficiency, and accountability of education management. The problem is that the Ministry of Religion must prepare an adequate budget by considering the numbers needed of religious education teachers at schools in the regions.

The advantage of religious education teachers' provision by the Ministry of Religion makes it easier to manage religious education teachers in schools to avoid shifting responsibilities between the two institutions, namely the Ministry of Religion and the Regional Government. However, on the other hand, there is still a problem with the absence of regulations governing the appointment of religious education teachers in schools under the full authority of the Ministry of Religion. The solution is in regulating the integration of madrasa education with religious education.

The regulations used are related to the development of religious education teachers and religious education supervisors, including PP No. 55 of 2007, Government Regulation Number 17 of 2010, PMA Number 16 of 2010, PMA Number 2 of 2012, and Regulation of the Minister of Education and Culture (Permendikbud) Number 15 of 2018. In coaching religious education teachers, religious education supervisors at schools face obstacles because the institution belongs 
to the Regional Government, but the guidance is substantive. Regarding learning activities, it is the authority of the Ministry of Religion from planning to supervision. The form of religious education teacher coaching can be in seminars, workshops, workshops, or similar activities such as developing sustainable potential. In implementing religious education teacher coaching through KKG and MGMP for Religious Education. However, they still face constraints of limited budget availability.

The career development of religious education teachers refers to PMA No.2 of 2012, Permenpan RB No. 21/2010, and Regulation of the Minister of Education and Culture (Permendikbud) No. 143/2014. Career development for religious education teachers is based on the employee job target assessment (SKP) of teachers through the school principal or head of the Pokjawas and fulfills administrative requirements and passes competency tests and training. The opportunities for religious education teachers in schools to become deputy principals, school principals, supervisors, and officials in the education office are very open, not differentiated from general subject teachers. The promotion of religious education teachers appointed by the Regional Government does not face sufficient problems through the BKD. Still, for those appointed by the Ministry of Religion IV / b and above through BKN, the process is getting longer. Another obstacle in which religious education teachers are required to collect credit scores from the learning process (PKB). Besides, religious education teachers appointed by the Ministry of Religion cannot be appointed as school principals or positions within Diana Pendidikan because this is the Local Government's full authority. Thus, it is necessary to make regulations that allow religious education teachers to be appointed by the Ministry of Religion to be appointed as school heads or positions within the Office Education.

Regarding the welfare of religious education teachers in schools, both public and private teachers receive certification allowances, regional allowances, additional honoraria, and a 13 and THR salary. For the regional allowance, each state religious education teacher, the Regional Government appointment, receives a regional allowance equal to that of general subject teachers, namely Rp. 3,339,000, - while private religious education teachers are given an additional honorarium of Rp. 300,000 per month. Meanwhile, religious education teachers in schools also receive a certification allowance. For religious education teachers with state status, there is no problem, while for private/honorary religious education teachers, the difficulty of obtaining an honorary degree from the Regent/mayor is one of the administrative requirements in applying for the certification allowance. The certification of religious education teachers in schools falls under the authority of the Ministry of Religion.

\section{Religious Education Teachers}

The procurement of religious education teachers in schools is the same as teachers' procurement in other fields of study, namely through recruitment, selection, written tests, and interviews based on databases. After being declared graduated, they are assigned to each school in need. The provision of religious education teachers in schools is under the Regional Government's authority through the Education Office. According to him, the procurement of religious education teachers through two channels is less effective because religious issues are not autonomous and have resulted in poor administration due to mutual reliance between the two agencies. Besides, each agency generally has different interests depending on its duties and functions. And suppose the appointment is not well coordinated between the two agencies. In 
that case, confusion will likely occur in terms of administration and guidance that will be carried out because of shifting responsibilities to one another.

\section{E. Supervisory for Religious Education}

The procurement of religious education teachers at schools uses two channels, namely through the Ministry of Religion and the Regional Government is not a problem because laws and regulations support it, such as Law Number 20 of 2003 concerning the National Education System, Law Number 14 of 2005 concerning Teachers and Lecturers, Government Regulation Number 55 of 2007 concerning Religious and Religious Education and PMA No.16 of 2010 concerning the procurement of religious education teachers in schools.

According to him, the procurement of religious education teachers by the education office is solely aimed at meeting the number of religious education teachers in schools given the Ministry of Religion's limitations in recruiting and meeting the needs of religious education teachers in schools.

Religious education teachers appointed by the Regional Government also have the opportunity to participate in education and training, seminars and workshops, or other activities held by the Education Office two or three activities each year related to increasing the insight and skills of religious education teachers. Also, in schools, religious education teachers are allowed to participate in various activities based on the Ministry of Religion's invitation. The hope is that in the future, the policy of managing religious education teachers cannot be separated from policies for implementing education in general.

\section{POLICY IMPLEMENTATION OF RELIGIOUS EDUCATION TEACHERS}

\section{A. Recruitment of Religious Education Teachers}

Procurement of religious education teachers in schools in Bandung City after regional autonomy is carried out jointly between the Ministry And the DKI Regional Government. Education authorities. The Regional Government / Education Office carries out the administration of GPA. Simultaneously, the guidance on substance related to the improvement and development of competence and professionalism is the Ministry of Religion's responsibility. However, for career development and assessments conducted by the Education Office.

The appointment of religious education teachers is tailored to the needs, the quota or the formation is adjusted to the Bandung city education office's needs. Initially, the school proposed the provision of religious education teachers, then the Education Office accepted the proposal and coordinated with the BKD. Then BKD proposes to BKN, which is then fulfilled by BKN according to the existing quota. In this proposal, the Education Office did not coordinate with the Ministry of Religion because each had the authority. However, it recognizes the need for coordination with the Ministry of Religion.

The Government or regional governments provide PP No. 55 of 2007, concerning religious education and religious education, article 6 paragraph (1), religious education educators in education units organized by the Government or local governments according to their respective authorities based on the provisions of the Legislation. Furthermore, PP No. 74 of 2008 
concerning teachers, specifically regarding the appointment and placement of educational units in article 58, states that the appointment and placement of teachers appointed by the Government and/or the Regional Government are carried out under the provisions of laws and regulations.

\section{B. Fostering Religious Education Teachers Religious}

Education teachers have an important position in developing students' understanding, living, and religious values. Seeing this, religious education teachers and teachers of other subjects, have a strategic role in implementing quality education. Therefore the Government must foster and develop and establish many policies on managing religious education teachers.

Explicitly in Law no. 22 of 1999 regarding the Regional Government states that the implementation of education is no longer the central government's responsibility and the Local Government's responsibility. In other words, the implementation of education is the responsibility of local governments, both in management and education supervision. In line with the Law in Law Number 32 the Year 2004, it is stated that regional autonomy is the right, authority, and obligation of an autonomous region to regulate and manage government affairs and local interests under statutory regulations. The provision of education and allocation of potential human resources at the provincial scale is the provincial Government's mandatory affairs that must be fulfilled (article 13 paragraph 1). Meanwhile, district or city governments only have compulsory affairs at the district or city scale in education provision (article 14 paragraph 1f).

In PP No. 17 of 2010 concerning the Management and Implementation of education in Chapter. II Article 2 that the Management of education is carried out by the Government, provincial governments, district/city governments, administrators of educational units established by the community and educational units or programs.

The view of the DKI Ministry of Religion. The Head and Kasi of PAI, local governments, supervisors, and teachers of religious education in charge of fostering religious education teachers stated that coaching should be a shared responsibility between the Ministry of Religion and the City Government through the Education Office. However, it is necessary to clarify the form of training for religious education teachers in schools, which is the Ministry of Religion and the Education Office's responsibility. The guidance like enhancing and developing the competence and professionalism of religious education teachers is the Ministry of Religion's responsibility, while forms of guidance related to administration, career development, welfare, and evaluation of religious education teachers are the Regional Government's responsibility.

So far, religious education teachers' coaching has been running well even though it has not reached all religious education teachers because an adequate development budget does not support it. With this limited budget, the guidance for GPA has not been maximized in quantity and quality. The number of coaching in the form of seminars, workshops, orientation, and training for religious education teachers has not reached all religious education teachers.

\section{Career Development and ranks of Religious Education Teachers}

There is still the treatment of local governments that have not positioned good religious education teachers in schools appointed by the Ministry of Religion and the Regional Government, for example, to fill the positions of school principals and structural positions in the Education Office. 


\section{The welfare of Religious Education Teachers}

In terms of incentives in the form of regional allowances, most religious education teachers have not received it, if any, it is relatively small compared to other teachers appointed by the Regional Government.

On the other hand, there are still complaints about religious education teachers' unclear fate who teach in public schools to implement certification due to bureaucratic dualism. So far, for salaries, it has been managed by the Ministry of National Education, while certification has been submitted to the Ministry of Religion. The policy is considered unfair for the 170,000 religious teachers who teach in public schools. This results in a limited quota for religious teachers to obtain certification so that the opportunity to get a professional allowance of one salary per month is also getting narrower. As for other teachers under the Ministry of Education, generally, the certification process and payment of the professional allowance are running smoothly.

\section{E. Constraints and solutions faced by the Head of PA, Kasi PA, PA Teachers, PA} Supervisors, and the Education Office

The implementation of religious educators in the regions still receives "discriminatory" treatment from the local Government. This is largely due to the incomplete understanding of the regional Government regarding the terms "education" and "religion" in the two laws. There are many partial interpretations that under the authority of local governments is education under the Ministry of National Education's auspices. Meanwhile, education under the Ministry of Religion's auspices is still under the Ministry of Religion's authority. So that there is an injustice of local government policies towards religious education teachers within the Ministry of Religion, one of which can be seen in the treatment of local governments on the welfare of religious education teachers.

\section{ANALYSIS}

\section{A. Religious Education Teacher Recruitment}

Policies The management policy for religious education teachers in the era of regional autonomy cannot be separated from regional autonomy implementation based on Law no. $22 / 1999$ is directed at improving public services and welfare, developing a democratic life, justice, equity, and maintaining a harmonious relationship between the central and regional governments.

Explicitly in Law no. 22 of 1999 regarding the Regional Government states that the implementation of education is no longer the central government's responsibility and the Local Government's responsibility. In other words, the implementation of education is the responsibility of local governments, both in management and education supervision. In line with the Law in Law Number 32 the Year 2004, it is stated that regional autonomy is the right, authority, and obligation of an autonomous region to regulate and manage government affairs and local interests under statutory regulations. The provision of education and allocation of potential human resources at the provincial scale is the provincial Government's mandatory affairs that must be fulfilled (article 13 paragraph 1). 
Meanwhile, district or city governments only have compulsory affairs at the district or city scale in education provision (article 14 paragraph 1f). Furthermore, in PP. The Government or regional governments provide 55 of 2007, concerning religious education and religious education, article 6 paragraph (1), religious education educators in education units organized by the Government or local governments according to their respective authorities based on the provisions of the Legislation. Furthermore, PP No. 74 of 2008 concerning teachers, specifically regarding the appointment and placement of educational units in article 58, states that the appointment and placement of appointed teachers by the Government and/or Local Government carried out under the regulations legislation's provisions. In PP No. 17 of 2010 concerning Management and Implementation of Education in Chapter. II Article 2 that the Management of education is carried out by the Government, provincial governments, district/city governments, administrators of educational units established by the community and educational units or programs.

The enactment of these laws and regulations encourages changes/shifts in the delivery of education towards decentralization of education, which is the delegation of part or all of the authority in the education sector to officials under it, or from the central Government regions. The implementation of regional autonomy should provide enlightenment in the Management of religious education teachers in schools. With the laws mentioned above and regulations it provides a great opportunity for the Ministry of Religion and the Regional Government to recruit and foster religious education teachers. Therefore, it is necessary to have good coordination between the Ministry of Religion and the Regional Government to appoint and foster religious education teachers at schools so that the Ministry of Religion and the Regional Government's responsibilities become clear. Based on statutory regulations, it is possible that the procurement/appointment of religious education teachers at schools can be carried out through two channels, namely the Ministry of Religion and the local Government.

Procurement through two channels is not a problem because laws and regulations support it. The appointment through two channels can be a solution in meeting the needs of religious education teachers in the regions. Furthermore, it is necessary to properly prepare regional regulations (Perda), which elaborates the existing statutory regulations. Also, it is realized that there is a budget limitation for the Ministry of recruiting Religious education teachers. Thus, the appointment through two channels can help meet the needs of religious education teachers needed by regions.

The problem that arises is that the Ministry of Religion has difficulty providing guidance related to competence and professionalism, career development, rank, and, in passing, religious education teachers' welfare at schools. If the Ministry of Religion wishes to have full authority in the Management of religious education teachers in schools, the need for a regulation on the appointment of religious education teachers at schools is integrated with the appointment of madrasa education teachers.

\section{B. Policy on Fostering Religious Education Teachers}

The responsibility for fostering religious education teachers has been the responsibility of the Ministry of Religion. Until now, coaching is still running well, but an adequate coaching budget does not support it. The welfare of religious education supervisors, as the spearhead of the development of religious education teachers, has not been paid attention to because of the limited regional government budget. This condition results in the development of religious 
education teachers not yet maximized in terms of quantity and quality. In terms of the number of coaching in the form of seminars, workshops, orientation, and training for religious education teachers, it has not reached all religious education teachers. As for qualitatively increasing professionalism is limited to the socialization of KTSP, it has not comprehensively addressed religious education teachers' duties. It is necessary to distinguish between the training of religious education teachers, which is the Ministry of Religion's authority, and which is the authority of the Local Government. For example, guidance related to the professional improvement of religious education teachers, education and training, religious education teachers' orientation, operational funds for religious education MGMP for all districts, and similar activities isstry of ReGovernment's authority contrast, those related to providing welfare or allowances for improving the income of religious education teachers are the Regional Government's authority.

The implementation of training for religious education teachers at schools by the Regional Government has not differentiated between religious education teachers' religion appointed by the Ministry of and the Regional Government. They both receive the same treatment in various matters, such as increased competence and professionalism, career development, and welfare.

The main authority for increasing the professionalism of religious education teachers is the Ministry of Religion's responsibility. However, these efforts to increase have not been implemented properly due to the limited budget available. Only a small proportion of religious education teachers have participated in activities to increase professionalism, such as seminars, workshops, and similar activities. The lack of available budget results in a lack of attention and guidance for religious education teachers from the Ministry of Religion. Meanwhile, the Regional Government at this time has not allocated an adequate budget for the guidance of religious education teachers. However, only allocate a budget according to the number of religious education teachers appointed by the Regional Government. Therefore, in the future, the Ministry of Religion needs to increase the allocation of adequate funds under the number of existing religious education teachers, both appointed by the Ministry of Religion and the Regional Government.

The KKG / MGMP for religious education in schools has not been able to play a good role because an adequate budget does not support them. Many activities related to improving the competence of religious education teachers, such as socializing the KTSP, developing KTSP, and activities related to improving the GPA's professionalism, have not been implemented. If an adequate budget supports it, it will contribute to increasing religious education teachers.

\section{Career Development Policy and Religious Education Teacher Rankings}

The career development of religious education teachers and other teachers is treated equally by the Regional Government. To become school principals, government structural officials, religious education teachers have the opportunity; the important thing is that they have the required competence and professionalism. The same applies to religious education teachers' career development to serve as homeroom teachers, vice principals, and as 
supervisors of religious education. Opinions and Desires of school principals, religious education teachers, the Ministry of Religion, and the Education Office on the career development of religious education teachers can be the Regional Government's authority only to propose and accept local government decisions.

D. Welfare Policy

Based on the results of interviews with religious education teachers regarding the provision of welfare allowances, they generally received what teachers received from other subjects. The regional government does not differentiate welfare allowances between religious education teachers and teachers of other general subjects. Religious education teachers strongly agree that the welfare allowance for religious education teachers at schools is the Regional Government's authority and responsibility.

The DP3 assessment of religious education teachers at schools is the Regional Government's authority through their direct supervisor, namely the school principal. The assessment given is based on religious education teachers' ability to complete tasks, which are their responsibility from various aspects, namely: work performance, responsibility, obedience, loyalty, honesty, cooperation, and leadership. The assessment conducted by the Ministry of Religion is only a portfolio for certification of religious education teachers.

\section{CLOSING}

\section{Conclusion}

1. Religious Education Teachers (GPA) do not yet know the regulations related to the Management and implementation of education, such as Law no. 22 of 1999 and Law No. 32 of 2004 concerning Regional Government, PP. 74 of 2008 concerning Teachers and Government Regulation No. 17 of 2010 concerning the Management and Implementation of education.

2. The Ministry of Religion experiences difficulties in providing guidance related to competence and professionalism, career development, rank, and in passing, the welfare of religious education teachers in schools.

3. Lack of coordination between the Education Office and the District / City Ministry of Religion in the recruitment and placement and guidance of GPAs.

4. Insufficient budget in developing GPA.

\section{Recommendations}

1. There needs to be the socialization of various regulations on the Management and implementation of religious education, such as Law no. 22 of 1999 and Law No. 32 of 2004 concerning Regional Government, PP. 74 of 2008 concerning Teachers and Government Regulation No. 17 of 2010 concerning the Management and Implementation of education.

2. By regulation, the appointment of Religious Education Teachers in schools is integrated with religious education teachers' appointment at madrasas.

3. The need for coordination between the Education Office and the Ministry of Religion at the Regional Office and District / City level in the recruitment and placement and guidance of GPAs.

4. The need for an adequate budget for training GPA in schools. 


\section{REFERENCES}

[1] AM, S. (1994) Interaction and Teaching and Learning Motivation, Teacher Guidelines, and Teacher Candidates. Jakarta: PT Raja Grafindo Persada.

[2] Amitembun, MA (1990) Classroom Management (Assessment for Teachers and Teacher Candidates. Bandung: IKIP.

[3] Arikunto, S. (1996) Classroom and Student Management (An Alternative Approach). Jakarta: PT. Raja Grafindo Persada.

[4] BPS Java Province ( 2017) Central Bureau of Statistics of West Java Province. Bandung.

[5] Depdikbud (1990) Big Indonesian Dictionary. Jakarta: PN Balai Pustaka.

[6] Gunawan, AH (1996) School Administration (Administration of Micro Education). Jakarta: PT Rineka Cipta.

[7] Hasibuan, MSP ( 2003) Management (Basics, Understanding, and Problems. Jakarta: Earth Literacy. [8] Husen, Syed Sajjad, et al. (1994) Towards the Collapse of Islamic Education, translated by Rahmani Astuti from the original title Crisis Muslim Education. Fifth. Bandung: Gema Risalah Press.

[9] Ma'rifataini, LD (2018) 'Article Needs Evaluation, Provision and Development of Islamic Religious Education Teachers in Schools', Penamas, 31 (2), p. 433. doi: 10.31330 / penamas.v31i2.248.

[10] Nawawi, H. (2005) Social Research Methods. Yogyakarta: Gadjah Mada University Press. [11] Umar, H. (1999) Human Resources in Organizations. Jakarta: PT. Rosdakarya youth.

[12] Wiradiharja, HM (1987) Dimensions of Leadership in Management. Jakarta: PN Balai Pustaka. 